Situs Jurnal : $\underline{\text { http://ejurnal.stiepancasetia.ac.id/index.php/jieb }}$

Jilid 4 Nomor 3 November 2018

Hal 391 - 410

\title{
PENGARUH MOTIVASI, KARAKTERISTIK INDIVIDU, KARAKTERISTIK PEKERJAAN DAN KARAKTERISTIK ORGANISASI TERHADAP PRESTASI KERJA KARYAWAN (STUDI PADA PT. PUTRA INDAH PERKASA BANJARBARU, KAL-SEL)
}

\section{Victor Fransditya Yudha*, Nurus Syamsi, dan Siti Madina}

\begin{abstract}
This study aims to examine the factors of motivation, individual characteristics, job characteristics, organizational characteristics of job performance either simultaneously (together) or partially on employee performance of PT. Putra Indah Perkasa Banjarbaru, Kal-Sel. Population and sample in this study are all employees PT.Putra Indah Perkasa Banjarbaru, Kal-Tues which amounts to 200 people. In this research used sampling method stratified random sampling taken at random with $25 \%$ sampling size that is 50 respondents. The results showed that: simultaneously variable motivation, Individual characteristics, job characteristics, and organizational characteristics have a significant effect on employee performance. While only partially motivation and job characteristics that have a significant effect. While individual characteristics and organizational characteristics have no effect on employee performance. Job characteristics variable has a dominant effect on employee work performance of PT. Indah Indah Perkasa Banjarbaru, KAL-SEL.
\end{abstract}

Keywords: Motivation, Individual Characteristics, Job Characteristics, Organizational Characteristics, employee performance

Abstrak: Penelitian ini bertujuan untuk menguji pengaruh motivasi, karakteristik individu, karakteristik pekerjaan, karakteristik organisasi terhadap prestasi kerja baik secara simultan (bersama-sama) maupun secara parsial terhadap prestasi kerja karyawan PT. Putra Indah Perkasa Banjarbaru, Kal- Sel. Populasi dan sampel dalam penelitian ini adalah seluruh karyawan PT.Putra Indah Perkasa Banjarbaru, Kal-Sel yang berjumlah 200 orang. Dalam penelitian ini digunakan metode pengambilan sample stratified random sampling yang diambil secara acak dengan ukuran sampling $25 \%$ yaitu 50 responden. Hasil penelitian menunjukan bahwa : secara simultan variable motivasi , karakteristik Individu , karakteristik pekerjaan, dan karakteristik organisasi berpengaruh sigifikan terhadap prestasi kerja karyawan. Sementara secara parsial hanya motivasi dan karakteristik pekerjaan yang berpengaruh signifikan. Sedangkan karakteristik individu dan karakteristik organisasi tidak berpengaruh terhadap prestasi kerja karyawan. Variabel Karakteristik Pekerjaan berpengaruh dominan terhadap prestasi kerja karyawan PT. Putra Indah Perkasa Banjarbaru, KAL-SEL.

Kata kunci : Motivasi, Karakteristik Individu, Karakteristik Pekerjaan, Karakteristik Organisasi, prestasi kerja karyawan.

\section{Latar Belakang}

Perubahan lingkungan eksternal yang meliputi berbagai aspek seperti teknologi, globalisasi, ekonomi, budaya dan politik menuntut organisasi untuk melakukan transformasi 
yaitu perubahan fundamental pada business image, baik dari sudut pandang konsumen maupun karyawan, memberikan tekanan pada penciptaan mindshare daripada market share, dan menghasilkan kesamaan pandangan antara konsumen dan karyawan.

Transformasi organisasi ini membentuk paradigma baru tentang manajemen sebagai fungsi organisasi (manajemen sumberdaya manusia) maupun sebagai sumberdaya untuk mencapai keunggulan bersaing yang berkelanjutan (sutained competitive advantage). Peran SDM sebagai sumberdaya dalam organisasi adalah sebagai penghasil knowledge, pembangunan social capital yang menjadikan organisasi memiliki distinctiveness (keunikan) dengan pesaingnya. Keuinikan tersebut tercipta karena adanya proses dan praktik-praktik SDM yang tidak mudah ditiru oleh organisasi lainnya sehingga menjadi sumber daya keunggulan bersaing bagi sebuah organisasi.

Manajemen sumberdaya manusia telah menjadi suatu hal yang penting dalam perusahaan , terutama perannya dalam memberikan keunggulan bersaing bagi perusahaan, serta dalam menghadapi kemajuan teknologi di masa mendatang ( Greer, 2001). Semua aktivitas sumberdaya manusia dalam perusahaan, yang meliputi perencanaan, penarikan dan pemilihan tenaga kerja, pelatihan dan pengembangan dan penilaian kinerja serta system imbalan,diarahkan agar dapat sejalan dengan tujuan organisasi yang ingin dicapai ( Fisher, 1993). Manajemen sumberdaya manusia memegang peran penting dalam menghubungkan aktivitas tersebut dengan tujuan strategis organisasi. Di sisi lain, strategi bisnis dapat dikembangkan untuk memberikan modal bagi keunggulan bersaing organisasi dalam sumberdaya manusia yang dimilikinya.

Semakin tumbuh dan berkembang suatu organisasi yang dibarengi dengan adanya tekanan eksternal maupun internal, akan membutuhkan perubahan dalam manajemen sumberdaya manusianya. Program manajemen sumberdaya manusia, system maupun pelaksanaannya harus diorganisir agar dapat sesuai dengan kebutuhan untuk berubah (Fisher, 1993). Dalam organisasi yang sedang tumbuh tersebut, sumberdaya manusia dipandang sebagai suatu sumber bagi keunggulan bersaing, dimana kompetensi yang membedakan dicapai melalui pengembangan keterampilan pekerjaan, kultur organisasi, proses manajemen maupun sistemnya (Greer, 2001).

Dalam studi tentang prilaku individu maupun organisasi, konsep yang paling banyak mendapat perhatian dari para pakar adalah masalah motivasi. Pemandangan sekilas setiap organisasi menunjukan bahwa beberapa orang tertentu bekerja lebih keras daripada yang lain. Seseorang yang memiliki kemampuan istimewa mungkin dikalahkan prestasinya oleh orang lain yang sesungguhnya kurang berbakat. Hal ini disebabkan dimilikinya motivasi yang tinggi yang tidak dimiliki oleh sebagian orang.

Dalam perkembangannya, para ahli telah banyak melakukan penelitian dan pengkajian mengenai faktor - faktor yang mempengaruhi motivasi individu dalam bekerja. Sehingga masalah motivasi sampai saat ini terus menjadi bahan perbincangan utama, baik melalui seminar-seminar atau pelatihan yang diprogramkan secara khusus untuk meningkatkan prestasi kerja bawahan maupun pimpinan.

Motivasi adalah suatu dorongan kehendak yang menyebabkan seseorang melakukan suatu perbuatan untuk mencapai tujuan tertentu. Motivasi berasal dari kata motif yang berarti "dorongan" atau rangsangan atau "daya penggerak" yang ada dalam diri seseorang. Menurut Weiner (1990) yang dikutip Elliot et al. (2000), motivasi didefenisikan sebagai kondisi internal yang membangkitkan kita untuk bertindak, mendorong kita mencapai tujuan tertentu, dan membuat kita tetap tertarik dalam kegiatan tertentu. Menurut Uno (2007), motivasi dapat diartikan sebagai dorongan internal dan eksternal dalam diri seseorang yang diindikasikan dengan adanya; hasrat dan minat; dorongan dan kebutuhan; harapan dan citacita; penghargaan dan penghormatan. Motivasi adalah sesuatu apa yang membuat seseorang 
bertindak (Sargent, dikutip oleh Howard, 1999) menyatakan bahwa motivasi merupakan dampak dari interaksi seseorang dengan situasi yang dihadapinya (Siagian, 2004).

Motivasi menjadi suatu kekuatan, tenaga atau daya, atau suatu keadaan yang kompleks dan kesiapsediaan dalam diri individu untuk bergerak ke arah tujuan tertentu, baik disadari maupun tidak disadari (Makmun, 2003). Motivasi seseorang dapat ditimbulkan dan tumbuh berkembang melalui dirinya sendiri-intrinsik dan dari lingkungan-ekstrinsik (Elliot et al., 2000; Sue Howard, 1999). Motivasi intrinsik bermakna sebagai keinginan dari diri sendiri untuk

Berdasarkan pengertian di atas, maka motivasi merupakan respon pegawai terhadap sejumlah pernyataan mengenai keseluruhan usaha yang timbul dari dalam diri pegawai agar tumbuh dorongan untuk bekerja dan tujuan yang dikehendaki oleh pegawai tercapai. Dari studi tentang motivasi ini, mengantarkan kita pada kenyataan bahwa manusia adalah mahluk yang multi dimensional, dimana manusia selain mempunyai kebutuhan biologis, juga mempunyai kebutuhan yang lain, yaitu kebutuhan pisikologis , kebutuhan rasa aman, social, penghargaan dan aktualisasi diri.

Manusia juga sebagai makhluk individu dan makhluk social yang secara alami mempunyai berbagai kekurangan dan keterbatasan, baik dalam kemampuan fisik, daya pikiran maupun terbatasnya waktu. Sementara aktivitas yang dilakukan semakin meningkat, sehingga mendorong manusia melakukan kerja sama dengan orang lain dan untuk memenuhi tuntutan tersebut salah satunya adalah dengan memasuki organisasi.

Pemahaman motivasi,,baik yang ada dalam diri karyawan maupun yang berasal dari lingkungan akan dapat membantu dalam meningkatkan kinerja (Sujak, 1990). Dalam hal ini seorang manajer perlu mengarahkan motivasi dengan menciptakan kondisi dimana para karyawan merasa terpacu untuk bekerja lebih keras agar kinerja yang dicapainya juga lebih tinggi.

Menurut Hellierigel san Slocum, bahwa alasan utama yang mempengaruhi motivasi adalah karakteristik individu, karakteristik pekerjaan dan karakteristik organisasi. Dengan demikian para pemimpin dalam meningkatkan kinerja karyawan harus dapat mempertimbangkan alasan factor yang dapat menciptakan motivasi kerja dan pengaruhnya terhadap perilaku para karyawan.

Dalam hal ini dapat diketahui bahwa motivasi merupakan salah satu alasan penting dalam organisasi yang dapat memberikan dan meningkatkan kontribusi pada perusahaan dimana perusahaan dapat memperoleh keuntungan/profit seperti yang diharapkan.

Menurut James (2004 : 87) "karakteristik individu adalah minat, sikap dan kebutuhan yang dibawa seseorang didalam situasi kerja." Minat adalah sikap yang membuat seseorang senang akan obyek kecenderungan atau ide-ide tertentu. Hal ini diikuti dengan perasaan senang dan kecenderungan untuk mencari obyek yang disenangi itu. Minat mempunyai kontribusi terbesar dalam pencapaian tujuan perusahaan, betapapun sempurnanya rencana organisasi dan pengawasan serta penelitiannya. Bila karyawan tidak dapat menjalankan tugasnya dengan minat gembira maka suatu perusahaan tidak akan mencapai hasil yang semestinya dapat dicapai.

Terkait mengenai kepuasan kerja menurut Okpara (2006:26) kepuasan kerja yang didapatkan setiap karyawan tidak sama karena kriteria mereka terhadap kepuasan kerja berbeda-beda. Hal ini berhubungan dengan masing-masing individu karyawan yang meliputu hal umur, jenis kelamin, status kawin dan masa kerja.

Karakteristik individu menurut Ratih Hurriyati (2005:79) merupakan suatu proses psikologi yang mempengaruhi individu dalam memperoleh, mengkonsumsi serta menerima barang dan jasa serta pengalaman karakteristik individu merupakan faktor internal (interpersonal) yang menggerakkan dan mempengaruhi perilaku individu. 
Karakteristik pekerjaan adalah sebuah pendekatan dalam merancang pekerjaan yang menunjukkan bagaimana pekerjaan dideskripsikan ke dalam lima dimensi inti yaitu keanekaragaman keterampilan, identitas tugas, arti tugas, otonomi dan umpan balik (Robbins dan Judge, 2007:268).

Pendekatan karakteristik pekerjaan merupakan tindak lanjut dari proses rancangan pekerjaan. Model karakteristik pekerjaan ini berupaya untuk menjelaskan situasi dan merancang pekerjaan efektif bagi individu dengan menggunakan pendekatan contigency (Kreitner dan Kinicki, 2005:264). Dalam istilah umum, dimensi inti pekerjaan adakah karakteristik umum yang ditemukan pada berbagai tingkatan pekerjaan. Dimensi inti dari karakteristik pekerjaan ini selanjutnya digambarkan sebagai berikut:

1. Keanekaragaman keterampilan (skill variety) adalah tingkat sampai dimana pekerjaan memerlukan individu yang mampu melakukan berbagai tugas yang mengharuskannya menggunakan keterampilan dan kemampuan yang berbeda.

2. Indentitas tugas (taks identity) : tingkat sampai dimana suatu pekerjaan membutuhkan penyelesaian dari seluruh proses bagian pekerjaan yang diidentifikasikan.

3. Arti tugas (task significance) adalah tingkat sampai dimana pekerjaan berpengaruh substansial dalam kehidupan atau pekerjaan individu lain.

4. Otonomi (autonomy) : tingkat sampai dimana suatu pekerjaan memberikan kebebasan, kemerdekaanm serta keleluasaan yang substansial untuk individu dalam merencanakan pekerjaan dan menentukan prosedur-prosedur yang akan digunakan untuk menjalankan pekerjaan tersebut.

5. Umpan balik (feedback) adalah tingkat sampai dimana pelaksanaan aktivitas kerja membuat seseorang individu mendapatkan informasi yang jelas dan langsung mengenai keefektifan kerjanya.

Abdul Azis Wahab (2008:4) menjelaskan beberapa karakteristik dari organisasi diantaranya adalah (1) Sebuah entitas sosial;( 2) Bertujuan atau diarahkan oleh tujuan (goal directed); ( 3) Memiliki sistem kegiatan terstruktur yang disengaja dan; (4) dengan batasbatas yang jelas. Sedangkan menurut Gerlof (1998:6) karakteristik dari sebuah organiasi yaitu : (1) Tujuan; (2) Orang; (3) Rencana.

Setiap orang punya kebutuhan dan harus terpuaskan dalam kehidupannya. Pada awalnya setiap orang menghabiskan waktunya untuk mencari makan, mencari tempat berlindung dan berpakaian. 'Organisasi' yang pertama mungkin terbentuk ketika orangorang melakukan kerjasama dan membagi tugas diantara mereka sendiri, sehingga akan ditemukan sesuatu yang dibutuhkan mereka dengan lebih mudah. Secara umum organisasi punya tiga karakter:

1. Pekerjaan, kekuatan, dan tanggung jawab komunikasi dibagi diantara para anggota untuk membantu organisasi mencapai visi, misi dan tujuannya. Sebagai contoh, tim sepak bola, setiap pemain punya tugas tertentu untuk dipertontonkan, pelatih punya kekuasaan untuk memutuskan siapa yang akan menjadi pemain dari tim dan permainan apa yang akan dipelajari dan dipraktekkan.

2. "Pusat kekuasaan" timbul di suatu organisasi untuk mengarahkan mereka menghadapi tujuan-tujuan mereka. Dalam organisasi bisnis, pusat kekuasaan berada pada dewan direktur yang memutuskan bagaimana uang akan digunakan dan produk apa yang akan dibuat, siapa yang menetapkan gaji yang memuaskan dan situasi bekerja; manager sumber daya manusia, siapa yang memutuskan standar dan kriteria seleksi untuk merekrut pekerja.

3. Organisasi akan menempatkan stafnya pada posisi yang sesuai dengan kompetensinya. Sebagai contoh, jika seseorang bekerja terlalu lambat dan tidak sesuai dengan standard, karyawan itu mungkin akan dipindahkan ke departemen lain sesuai 
dengan kompetensi dimana kecepatan bekerja tidak diperlukan. Orang lain yang bekerja cukup cepat akan ditempatkan ditempat tersebut (Zulfikar; QMS jurnal;2012).

Demikian pula halnya dengan persoalan yang dihadapi oleh PT. Putra Indah Perkasa Banjarbaru, Kalimantan Selatan. Dalam kurun waktu dua tahun terakhir ini, perusahaan mengalami penurunan prestasi kerja. Penurunan tersebut dapat dilihat dari kecenderungan penurunan output keseluruhan, baik dilihat dari aspek produksi maupun penjualan. Setelah dilakukan kajian pendahuluan dengan menggunakan data-data yang ada, factor utama penurunan prestasi perusahaan disebabkan oleh penurunan prestasi kerja karyawannya.

Prestasi kerja, sebagaimana diuraikan sebelumnya, sangat dipengaruhi oleh factor motivasi. Factor motivasi yang mempengaruhi prestasi kerja karyawan pada PT. Putra Indah Perkasa Banjarbaru, Kalimantan Selatan dapat dikelompokan dalam 4 jenis, yaitu (1) Motivas, (2) karakteristik individu, (3) karakteristik pekerjaan, dan (4) karakteristik organisasi.

Berdasarkan pada kondisi tersebut di atas, maka penulis tertarik untuk melakukan penelitian dan pengamatan terhadap masalah : "Pengaruh Motivasi Karakteristik Individu, Karakteristik Pekerjaan dan Karakteristik Organisasi terhadap Prestasi Kerja Karyawan ( studi pada PT. Putra Indah Perkasa Banjarbaru Kal-Sel)", dengan tujuan penelitian sebagai berikut:

1. Untuk mengetahui dan menganalisis pengaruh motivasi, karakteristik individu, karakteristik pekerjaan dan karakteristik organisasi, secara bersama-sama (simultan) terhadap prestasi kerja karyawan PT. Putra Indah Perkasa Banjarbaru, Kalimantan Selatan.

2. Untuk mengetahui dan menganalisis pengaruh motivasi, karakteristik individu, karakteristik pekerjaan dan karakteristik organisasi, secara parsial terhadap prestasi kerja karyawan PT. Putra Indah Perkasa Banjarbaru, Kalimantan Selatan.

3. Untuk mengetahui variable manakah dari motivasi, karakteristik individu, karakteristik pekerjaan dan karakteristik organisasi yang berpengaruh dominan terhadap prestasi kerja karyawan PT. Putra Indah Perkasa Banjarbaru, Kalimanta Selatan.

\section{Kajian Literatur}

Konsep mengenai sumberdaya manusia telah ada sejak lama dan telah banyak dikembangkan oleh para peneliti perilaku organisasi . konsep sumberdaya manusia lebih banyak mempertimbangkan sifat-sifat manusia walaupun konsep-konsep tersebut berbeda satu sama lain, akan tetapi tetap sama, yaitu dengan tujuan untuk usaha pengembangan pemahaman terhadap sifat manusia.

Salah satunya adalah dengan menganalisakan kembali prinsip-prinsip dasar tersebut, seperti yang di kemukakan oleh Nadler dalam Thoha (1992) bahwa, prinsip-prinsip dasar perbedaan prilaku manusia disebabkan adanya perbedaan dalam hal kemampuan, kebutuhan, persepsi pola piker, dan pola bertindak serta minat.

Manusia dilahirkan dengan perbedaan antara satu sama lainnya. Salah satunya adalah perbedaan kemampuan yang membawa seseorang berbeda pula dalam prilaku. Prinsip dasarkemampuan adalah untuk memahami mengapa seseorang berbuat dan berprilaku berbeda dengan yang lain. Keanekaragaman kebutuhan manusia akan membuat mereka berprilaku berbeda antara yang satu dengan yang lainnya. Ahli ilmu perilaku mempunyai statement, perbedaan perilaku itu terdorong oleh serangkaian kebutuhan. Kebutuhan yang dimaksut adalah beberapa pernyataan didalam diri seseorang (internal state) yang menyebabkan seseorang berperilaku untuk mencapainya sebagai hasil.

Perbedaan pola pikir dan pola bertindak merupakan salah satu cara untuk menjelaskan bagaimana seseorang membuat pilihan dari sejumlah alternative perilaku yang ada. Semua individu cenderung mengevaluasi terlebih dahulu sesuatu yang mereka alami dengan cara 
senang atau tidak senang. Dengan perasaan senang dan tidak senang ini akan menjadikan seseorang berbuat yang berbeda dengan orang lain dalam rangka menanggapi sesuatu hal.

Perilaku manusia pada dasarnya didorong oleh suatu keinginan untuk memenuhi kebutuhannya. Setiap manusia mempunyai motivasi atau dorongan yang berbeda-beda antara satu orang dengan orang yang lain. Motivasi juga akan mengarahkan tindakan seseorang pada tujuan yang diinginkan dan manusia mau melakukakn sesuatu jika sesuai dengan keinginan yang dirasakan.

Pada dasarnya perilaku manusia dimulai atau ditimbulkan oleh adanya motivasi. Hani Handoko (1992), mengemukakan bahwa motivasi adalah keadaan dalam diri pribadi seseorang yang mendorong keinginan individu untuk melakukan kegiatan-kegiatan guna mencapai tujuan. Sedangkan Robbins (1996) mendifinisikan motivasi sebagai kesediaan untuk melakukan upaya yang tinggi kearah tujuan organisasi, yang dikondisikan oleh kemampuan upaya itu untuk memenuhi suatu kebutuhan individu.

Berikut ini dijelaskan beberapa pengertian yang dikemukakan oleh para penulis tentang motivasi:

1. Sukanto dan Handoko (1986), mendifinisikan motivasi sebagai keadaan dalam diri pribadi seseorang yang mendorong keinginan individu untuk melakukan kegiatankegiatan tertentu guna mencapai suatu tujuan. Jadi motivasi menurut pendapat ini adalah yang ada pada seseorang yang mewujudkan suatu perilaku yang diarahkan pada tujuan mencapai sasaran kepuasan.

2. Vroom, (dalam Gibson, 1984), mendifinisikan motivasi sebagai sutu proses yang menentukan pilihan antara beberapa alternative dari kegiatan sukarela. Sebagian besar perilaku dipandang sebagai kegiatan yang dapat dikendalikan orang secara sukarela,dank arena itu dimotivasi.

3. Wahjosumidjo (1984), motivasi dapat diartikan sebagai sutu proses psikologis yang mencerminkan interaksi antara sikap, kebutuhan, persepsi, dan keputusan yang terjadi pada diri seseorang. Proses psikologis timbul diakibatkan oleh factor didalam diri seseorang itu sendiri yang disebut intrinsic atau extrinsic.

4. Kreitner dan kinicki (2000), motivasi merupakan proses psikologis yang meningkatkan dan mengarahkan perilaku untuk mencapai tujuan.

Individu ialah subyek organisasi yang memiliki karakter berbeda-beda berdasarkan kebutuhan dan pengalamannya. Ciri-ciri itu membedakannya dari individu yang lain. Menurut Thoha (1992) individu membawa kedalam tatanan organisasi kemampuan, kebutuhan, kepercayaan pribadi, pengharapan dan pengalaman masa lalunya. Semua itu adalah karakteristik yang dipunyai individu dan karakteristik ini akan memasuki suatu lingkungan baru, yakni organisasi tau lainnya. Sujak, (1990) mengatkan bahwa: karakteristik individu yang berbeda-beda,meliputi kebutuhan, nilai,sikap dan minat. Perbedaan tersebut akan dibawa oleh individu ke dalam dunia kerja sehingga motivasi setiap individu akan bervariasi. Menurut Gibson, et al (1996) dan ahli-ahli lainnya, karakteristik individu terdiri dari:

1. Variabel psikologis (ciri kepribadian) kebutuhan non-material nilai, sikap dan minat;

2. Variabel biologis (ciri individu):usia, kebutuhan material, masa kerja, jenis kelamin, status perkawinan, dan banyaknya tanggungan;

3. Variabel fisiologis ( ciri fisik individu), yaitu: kemampuan dasar meliputi kemampuan intelegensial /mental dan kemampuan fisik;

4. Variabel lingkungan, yaitu: keturunan atau keluarga, kelas social dan kebudayaan.

Sedangkan variable-variabel lain dari karakteristik individu yaitu: persepsi, motivasi, pengambilan keputusan, pembelajaran atau pendidikan dan kesempatan. Berikut ini di 
uraikan variable-variabel karakteristik individu, sehingga terlihat relevansinya dengan permasalahan penelitian.

1. Kebutuhan Non Material

Kebutuhan dapat pula dibedakan menjadi dua jenis yaitu: kebutuhan material dan kebutuhan non material. Kebutuhan non material dapat diartikan sebagai suatu kebutuhan yang tidak bisa dipenuhi oleh segala sesuatu yang berwujud nyata. Yang termasuk dalam kebutuhan non material meliputi:
a. Kasih sayang
b. Keamanan
c. Otonomi
d. Status (pengakuan atas kedudukan/perhatian yang layak)
e. Penghargaan diri/harga diri $=$ martabat
f. Prestasi
g. Aktualisasi,

\section{Nilai}

Nilai yaitu harga (dalam arti taksiran), harga sesuatu (uang misalnya), jika diukur atau ditukarkan dengan yang lain, angka kepandaian (member angka), kadar mutu, sedikit isi missal makanan yang tinggi kalori dan proteinnya; sifat-sifat (hal-hal) yang penting dan berguna bagi kemanusiaan. Misal nilai-nilai agama perlu kita indahkan. (Kamus Bahasa Indonesia,1992). Nilai-nilai amat penting untuk mempelajari perilaku organisasi karena nilai meletakan pondasi untuk memahami sikap dan motivasi serta nilai mempengaruhi persepsi kita dalam menjalankan manajemen yang efektif, karena nilai mempengaruhi persepsi terhadap tujuan dan cara untuk mencapai suatu tujuan tersebut. Akibatnya nilai dapat memperkeruh obyektivitas dan rasionalitas. Dari pola dan pengembangan struktur dan proses organisasi, samapai pada pengujian gaya kepemimpinantentu dan evaluasi hasil karya bawahan, sitem nilai itu akan meresap dan mempunyai pengaruh yang besar, bagi efektivitas organisasi.

3. Sikap dan perilaku

Sikap adalah pernyataan atau pertimbangan evaluasi mengenai obyek, orang atau peristiwa. Sikap mencerminkan perasaan orang terhadap sesuatu. Factor yang menentukan perilaku serta erat hubungannya dengan persepsi, kepribadiaan, belajar dan motivasi. Sikap didefinisikan sebagai kesiap siagaan mental, yang diorganisasikan lewat pengalaman yang mempunyai pengaruh tertentu kepada tanggapan seseorang terhadap orang, obyek dan situasi yang berhubungan dengannya (Robbins, 1992). Apabila anakanak mencapai umur sepuluh tahun, mereka lebih kuat dipengaruhi oleh teman sejawat/kelompok teman karena mereka ingin pengakuan diterima oleh orang lain, mereka sedang mencari bentuk kesamaan dengan merubah sikap mengikuti sikap kelompok. Selanjutnya, model perilaku ini dapat diterapkan pada semua karyawan baik manajeman maupun non manajemen. Dalam perkembangan perilaku tiap-tiap individu memiliki ke khasan yang berbeda namun yang mendasari perkembangan perilaku itu sama, yang diasumsikan sebagai berikut:

a. Perilaku timbul karena suatu sebab;

b. Perilaku diarahkan kepada tujuan;

c. Perilaku yang mengarah pada tujuan dihambat oleh adanya gangguan berupa: kegelisahan,konflik dan frustasi; dan

d. Perilaku timbul karena motivasi namun sebaliknya motivasi juga mungkin timbul karena adanya kendala. 
Pada dasarnya perilaku pada semua orang adalah sama, yang membedakan karena adanya variable/cirri-ciri psikologis, fisiologis dan lingkungan serta adanya kendalakendala. Variable itu semua telah ada sebelum ia memasuki organisasi pekerjaan. Oleh karena itu wajar bila variable-variabel tersebut amat mempengaruhi perilaku individu dalam pekerjaannya. Secara singkat dapat dikatakan bahwa variable-variabel diatas, kesemuanya mempengaruhi keputusan individu untuk berperilaku dan bertindak. Namun dalam kaitan dengan motivasi pegawai untuk mencapai prestasi yang bagus maka variable nilai dan sikap dibandingkan variabel-variabel yang lain.

\section{Minat}

Minat adalah kecenderungan hati yang tinggi terhadap sesuatu, gairah, keinginan, menyukai atau menyenangi (Kamus Bahasa Besar Indonesia, 1990).

5. Usia

Dikatakan oleh Robbins, (1996;79) bahwa makin tua usia pekerja, makin sedikit kesempatan mendapat pekerjaan alternative. Namun disamping itu pekerja yang tua cenderung rendah tingkat kemangkiran atau absensinya, artinya mereka hanya absen hanya jika kesehatannya terganggu (sakit). Usia dalam kaitan pengaruhnya terdapat motivasi pegawai terletak pada kesediaan atau kesetiaannya yang lebih di banding pegawai yang lebih muda dan matang emosi atau tempramennya Nampak pada kinerja atau penampilannya. Namun, usia tidak terkait langsung dengan produktifitasnya.

\section{Kebutuhan Material}

Manusia sebagai mahluk yang secara biologis memerlukan kebutuhan material untuk mempertahankan kehidupannya. Kebutuhan material tersebut dimaksut berupa: makanan, minuman, gaji, pakaian, perumahan, kendaraan, insentif/bonus, tunjangan, santunan.

7. Masa Kerja (pengalaman)

Masa kerja juga merupakan variable yang ampuh dalam meramalkan pergantian karyawan. Dibuktikan, Robbins, (1996:81). Bahwa masa kerja pada suatu pekerjaan sebelumnya dari seseorang karyawan merupakan suatu peramal yang tepat dari keluaran karyawan itu di masa depan. Hal ini membuktikan adanya tingkat kepuasan kerja cukup mantap dari masa kerja. Hubungan masa kerja dengan kepuasan kerja adalah lebih positif dibandingkan antara usia kronologis dengan kepuasan kerja.

\section{Jenis Kelamin}

Dalam mengamati masalah perbedaan jenis kelamin pria dan wanita ialah apakah kinerja wanita sama dengan pria? Penjelasan Robbins (1996;80), antara lain bahwa beberapa studi psikologis yang dilakukan menunjukan bahwa wanita lebih bersedia mematuhi otorita sedang pria lebih agresif dan lebih besar kemungkinan memiliki pengharapan sukses. Perkembangan 25 tahun in, kadar partisipasi wanita meningkat pesat dalam angkatan kerja menyebabkan perubahan susunan peran pria dan wanita menjadi seimbang dan tidak berbeda tentang produktivitas mereka dan tingkat kepuasan kerja mereka.

\section{Status Perkawinan}

Tidak ada cukup bukti atau studi bahwa perkawinan mempunyai dampak terhadap produktivitas. Bahkan tidak ada riset yang memburu keterangan tentang status selain menikah; bujangan, janda/duda atau pasangan hidup bersama tanpa menikah serta pengaruhnya terhadap kinerja dan kepuasan kerjanya. Namun, dari suatu riset yang konsisten, menunjukan bahwa karyawan yang menikah lebih sedikit absensinya, 
mengalami tingkat pergantian yang lebih rendah, dan lebih puas dengan pekerjaannya daripada yang bujangan. (Robbins, 1996). Alasannya mungkin karena perkawinan memaksakan tanggung jawab yang meningkat, dan dapat membuat suatu pekerjaan yang ajeg (steady), lebih berharga dan penting.

10. Banyaknya Tanggungan Keluarga

Sangat sedikit riset tentang hubungan antara banyaknya tanggungan yang dipunyai karyawan dengan absensi, pergantian, kepuasan kerja dengan produktivitas. Namun bukti yang kuat, menyatakan bahwa banyak anak dari seorang karyawan mempunyai korelasi yang positif dengan absensi dan kepuasan kerja. (Robbins, 1996;81).

11. Kemampuan Dasar

Kemampuan dasar adalah kemampuan, kesanggupan, kecakapan, kekuatan, kelayakan, kekayaan, kuasa untuk melakukan sesuatu (Kamus Besar Bahasa Indonesia, 1990).

12. Persepsi

Menurut Gibson, et al (1996), persepsi ialah proses pemberian arti terhadap lingkungan oleh seorang individu. Persepsi meliputi: pengetahuan, cakupan penerimaan serta penafsiran terhadap objek (stimulus/input), tanda dan pengalaman individu bersangkutan, yang diorganisasikan dengan cara tertentu sehingga dapat mempengaruhi perilaku dan membentuk sikap. Oleh Karena setiap individu memberi arti sendirisendiri terhadap stimulus (input) maka pemberian arti itu akan berbeda meski objek yang dilihat sama. Persepsi bertautan dengan cara mendapatkan pengetahuan khusus tentang objek/kejadian pada saat tertentu, dan kejadian kapan saja stimulus menggerakan indra.

13. Pendidikan

Menurut poerwono, (1982) pendidikan merupakan suatu pembinaan dalam proses perkembangan manusia untuk berpikir sendiri dan mendorong berkembangnya kemampuan dasar yang ada padanya. Menurut Nadler(1990) dalam swasto (1996), pendidikan adalah proses pembelajaran yang mempersiapkan individu untuk pekerjaan yang berbeda pada masa yang akan datang. Pendidikan di desain untuk memungkinkan pekerja belajar tentang perbedaan pekerjaan dalam organisasi yang sama. Dengan demikian pendidikan karyawan penting artinya bagi suatu organisasi. Poerwono, (1982;74): untuk menjamin agar tiap bidang dalam suatu bentuk badan usaha silaksanakan oleh tenaga-tenaga dengan kecakapan dan keahlian dibidangnya masingmasing maka telah menjadi keyakinan dalam tata personalia perlunya pendidikan.

14. Pengambilan Keputusan

Keputusan, hakekatnya adalah suatu pengambilan atau pembuatan pilihan dari antara dua alternative atau lebih (Robbins, 1996).

15. Kesempatan

Kesempatan (Kamus Besar Bahasa Indonesia, 1990) didefinisikan sebagai peluang yang diperoleh/keleluasaan yang didapat oleh seseorang, untuk melaksanakan sejumlah kegiatan. Kesempatan bekinerja juga harus diperhitungkan untuk meramalkan kinerja karyawan karena betapapun seseorang termotivasi, bersedia dan mampu namun bila kesempatan menjadi kendala maka ia tidak akan sukses berprestasi/berkinerja yang tinggi. Oleh karena itu dalam menentukan orang yang tepat untuk diberikan kesempatan manajemen harus menggunakan alat performance appraisal yaitu teknik untuk mendapat 
hasil yang lebih baik dari individu, kelompok atau organisasi, (Swasto, 1997) dan Kempton (1995).

Rangkaian dimensi dari pekerjaan jika dihubungkan dengan keadaan psikologi, akan dapat memberikan hasil antralain: motivasi kerja intern yang tinggi, prestasi kerja yang berkualitas tinggi, kepuasan kerja yang tinggi dan kemangkiran serta pertukaran kerja yang rendah. Adapun keadaan psikologis menujukan pada pekerjaan yang dapat mencapai tiga keadaan psikologis yang kritis yaitu sebagai berikut:

1. Pekerja harus menghayati pekerjaan sebagai sesuatu yang berarti atau penting.

2. Pekerja harus bertanggung jawab atas hasil pekerjaannya dan atas produk yang diusahakannya secara pribadi.

3. Pekerja harus dapat memastikan dengan cara yang teratur dan handal, bagaimana hasil usahanya, apa yang telah dicapai dan memuaskan atau tidak, Schein (1991) dalam sudjak (1990)

Berdasarkan beberapa keterangan di atas maka karakteristik pekerjaan diupayakan dapat memberikan kepuasan kerja. Kepuasan kerja yang tinggi merupakan salah satu pendorong bagi individu untuk meningkatkan kesediaannya untuk ikut aktif dalam organisasi. Dengan adanya kepuasan akan menghindari kemangkiran dan keinginan pekerja untuk keluar dari organisasi. Oleh karena itu untuk menghindari kemangkiran dan perpindahan pekerja dari organisasi, perlu ditingkatkan kepuasan kerja.

Berdasarkan pendapat di atas, maka karakteristik pekerjaan merupakan dimensi inti dalam melakukan reorganisasi pekerjaan. Karakteristik pekerjaan yang dimaksut dalam penelitian ini meliputi beberapa factor sebagaimana di bawah ini:

1. Ragam keterampilan, identitas tugas, dan arti tugas.

a. Ragam keterampilan menunjukan bahwa aneka pekerjaan menuntut adanya keterampilan yang bermacam-macam.Robbins, (1996), menyatakan bahwa karyawan cenderung menyukai pekerjaan-pekerjaan yang member mereka kesempatan untuk menggunakan keterampilan dan kemampuan mereka dan menawarkan beragam tugas, keabsahan dan umpan balik mengenai betapa sebaiknya dikerjakan. Karakteristik inilah yang membuat pekerjaan menantang. Pekerjaan yang kurang menantang menciptakan kebosanan tetapi pekerjaan yang terlalu banyak menantang menciptakan frustasi dan kegagalan.pada kondisi sedang kebanyakan karyawan akan mengalami kesenangan dan kepuasan.

b. Identitas tugas menurut Schein (1983) Dalarn Sudjak, (1990) merupakan suatu tingkat dalam pekerjaan yang mengharuskan penyelesaian pekerjaan yang nyata. Melaksanakan sutu pekerjaan dari awal hingga akhir dengan hasil nyata. Identitas tugas membantu memperkuat serta meningkatkan komitmen karyawan pada organisasi dengan diketahui sejauh mana karyawan melaksanakan seluruh pekerjaan secara utuh dan dapat diidentifikasi hasil-hasil usaha mereka, sehingga pekerjaan tersebut benarbenar dapat dihayati dan menimbulkan kebetahan karyawan pada pekerjaannya.

c. Arti tugas menurut Schein (1983) dalarn Sudjak (1990) merupakan tingkatan dalam pekerjaan yang mempunyai dampak besar atas kehidupan orang lain baik dalam organisasi maupun di luar organisasi.arti tugas dapat digunakan untuk mengetahui sejauh mana sebuah pekerjaan menuntut pada gilirannya akan menuntut komitmen karyawan terhadap organisasi.

\section{Otonomi}

Otonomi menurut Schein (1983) dalarn Sudjak (1990) merupakan suatu tingkatan dalam pekerjaan yang memberikan pekerja kebebasan, kemandirian dan kebijakan penjadwalan 
pekerjaan dan menetukan pekerjaan harus dilaksanakan. Menurut Robbins, (1996) dengan tinggkat keterlibatan kerja yang tinggi ada kecenderungan rendahnya tingkat absensi dan permohonan berhenti dari pekerjaannya. Dengan otonomi berarti seseorang pegawai memperoleh kebebasan/berwenang mengatur waktu kerja, menetapkan prosedur penyelesaian pekerjaan dan karena keterlibatan kerja yang tinggi itu tumbuhlah rasa tanggung jawab terhadap hasil kerjanya.

\section{Umpan Balik}

Umpan balik merupakan tingkat dimana pekerja mendapatkan informasi mengenai efektif usahanya serta pengetahuan tentang pelaksanaan tugas dan hasil kerja atau kinerja dan suatu pekerjaan yang dilakukan. Umpan balik akan meningkatkan kesertaan pegawai pada organisasi karena dengan umpan balik karyawan menerima informasi yang mengungkapkan prestasinya sehingga paling tidak akan meningkatkan kepuasan karyawan akan hasil kerjanya.

Karakteristik organisasi ialah norma-norma organisasi yang akan mempengaruhi tindakan pegawai dan kesadarannya dalam aktivitas sehari-hari saat bekerja, Swasto, (1997). Karakteristik organisasi meliputi: kebijaksanaan organisasi, kultur, gaya kepemimpinan, program pengembangan karier dan system kompensasi. Karakteristik tersebut mempengaruhi pegawai untuk memotivasi karier mereka.

1. Kultur dan Kerjasama

Menurut Swasto (1996), dengan mengutip antara lain dari Stoner (1995), salah satu dari item karier lingkungan kerja (organisasi) adalah kultur organisasi. Individu yang mempunyai tingkat pilihan yang tinggi menunjukan tingkat kepuasan yang lebih tinggi untuk belajar, lebih bereaksi positif dan mempunyai kinerja yang lebih baik daripada, yang mempunyai tingkat pilihan criteria latihan yang rendah. Sedangkan persepsi lingkungan kerja juga berhubungan dengan motivasi peserta latihan untuk belajar. Individu dengan tingkat perencanaan karier dan keterlibatan pekerjaan tinggi juga akan mempunyai motivasi latihan yang tinggi.

2. Kepemimpinan dan Gaya Kepemimpinan

Kepemimpinan adalah kemampuan menggerakkan dan mengarahkan suatu tindakan pada diri seseorang atau kelompok untuk mencapai tujuan tertentu pada situasi tertentu. Dalam hal ini posisi manajer merupakan posisi kunci yang menyelaraskan proses kerjasama antara manusia dalam organisasinya. Kepemimpinan seseorang amat dipengaruhi oleh latar belakang budaya yang berbeda-beda namun keterampilan kepemimpinan umunya terdiri dari:
a. Pemberian kuasa (Enpowerment).
b. Intuisi (Intuition).
c. Pemahaman Diri ( Self Understanding).
d. Pandangan (Vision).
e. Nilai Keselarasan (Congruence Value).

Kepemimpinan yang efektif menurut Robert House dalam Sudjak (1990) melibatkan "penyeleksian gaya" yang paling sesuai dengan variable situasional tertentu. Gaya kepemimpinan yang mendominasi perilaku pimpinan ada empat macam yaitu:
a. Gaya kepemimpinan yang berorientasi pada prestasi (achievement Oriented Leadership).
b. Gaya kepemimpinan direktif (Directive Leadership).
c. Gaya kepemimpinan partisipatif (Paticipative Leadership). 


\section{d. Gaya kepemimpinan suportif (Supportive Leadership)}

\section{Kebijakan Organisasi}

Kebijakan adalah pedoman untuk bertindak (Solichin, 1995), kebijaksaan ialah peraturan yang dipedomani untuk melaksanakan tugas pekerjaan (Kamus Besar Bahasa Indonesia, 1990). Kebijaksanaan terdiri dari: prosedur staffing, prosedur kerja, design pekerjaan, system penggajian dan pemberian penghargaan serta program pengembangan pegawai dan pelatihan.

a. Prosedur staffing ialah langkah -langkah kegiatan untuk pembagian tugas pekerjaan.

b. Prosedur kerja ialah langkah kegiatan untuk penyelesaian pekerjaan.

c. Design pekerjaan ialah rancangan tentang pekerjaan, pengayaan atau penambahan jenis atau penganeka ragaman pekerjaan, spesialisasi pekerjaan, rotasi dan jadwal waktu kerja yang fleksibel.

d. System penggajian dan pemberian penghargaan ialah pengaturan pemberian gaji dan penghargaan lainnya.

e. Program pengembangan karier pegawai di masa yang akan datang baik melalui pendidikan dan pelatihan, promosi maupun pembentukan badan penilaian kualitas produktivitas pegawai.

Prestasi kerja atau juga disebut kinerja merupakan suatu tingkat dimana para karyawan mencapai persyaratan-persyaratan pekerjaan. Penilaian kinerja merupakan proses yang mengukur kinerja karyawan yang menyangkut aspek kualitatif dan kuantitatif dari pelaksanaan pekerjaan (Simamora, 1995).

Pendapat yang hamper sama juga dikemukakan oleh Bernardin \& Russel (1993), bahwa kinerja karyawan adalah catatan perolehan yang dihasilkan dari fungsi suatu pekerjaan tertentu atau kegiatan selama suatu periode waktu tertentu. Jadi kinerja berkenaan dengan hasil pekerjaan yang dicapai oleh karyawan dalam suatu periode. Dalam hal ini kinerja berkaitan dengan kuantitas maupun kualitas pekerjaan yang dihasilkan.

Berdasarkan pada tingkat kepentingannya, maka penilaian prestasi kerja bertujuan untuk:

1. Meningkatkan kemampuan karyawan.

2. Identifikasi factor penghambat kinerja.

3. Menetapkan kebijakan strategis untuk mengukur kinerja,

heneman, Schwab \& Fossum (1981), mengemukakan bahwa secara umum, pengukuran kinerja mencakup dua kegiatan utama, yaitu: 1)identifikasi dimensi kerja,dan 2) penetapan standar kinerja. Identifikasi dimensi kerja mencakup semua unsur yang akan di evaluasi dalam pekerjaan masing-masing karyawan dalam suatu oraganisasi. Dimensi ini memcakup berbagai criteria yang sesuai untuk digunakan dalam mengukur hasil pekerjaan yang telah diselesaikan. Dharma (1989), menyatakan bahwa hamper seluruh cara pengukuran kinerja mempertimbangkan hal-hal sebagai berikut:

1. Kualitas kerja, yaitu jumlah yang harus diselesaikan.

2. Kualitas, yaitu mutu yang dihasilkan.

3. Ketepatan waktu, yaitu kesesuaian dengan waktu yang telah direncanakan,

Sedangkan Bernardin dan Russel (1993), mengemukakan enam kinerja pokok untuk mengukur kinerja, yaitu:

1. Quality.

2. Quantity.

3. Timeliness. 
4. Cost-effectiveness.

5. Need for supervision.

6. Interpersonal impact.

Penetapan standart diperlukan untuk mengetahui apakah kinerja karyawan telah sesuai dengan sasaran yang diharapkan, sekaligus melihat besarnya penyimpangan dengan cara membandingkan antara hasil pekerjaan secara actual dengan hasil yang diharapkan. Yang dimaksut dengan standart adalah tolak ukur bagi kinerja yang akan dievaluasi (Snow \& Alexander, 1992, dalam cushway, 1996).

Suatu prestasi akan mudah diperoleh apabila ada motivasi. Motivasi tidak terlepas dari kemauan diri sendiri dan dorongan pihak lain. Karakteristik individu, karakteristik pekerjaan dan organisasi merupakan bagian dari motivasi. Berdasarkan latar belakang masalah, tujuan penelitian dan tujuan teoritis, maka dapat digambarkan kerangka konseptual penelitian sebagai berikut:

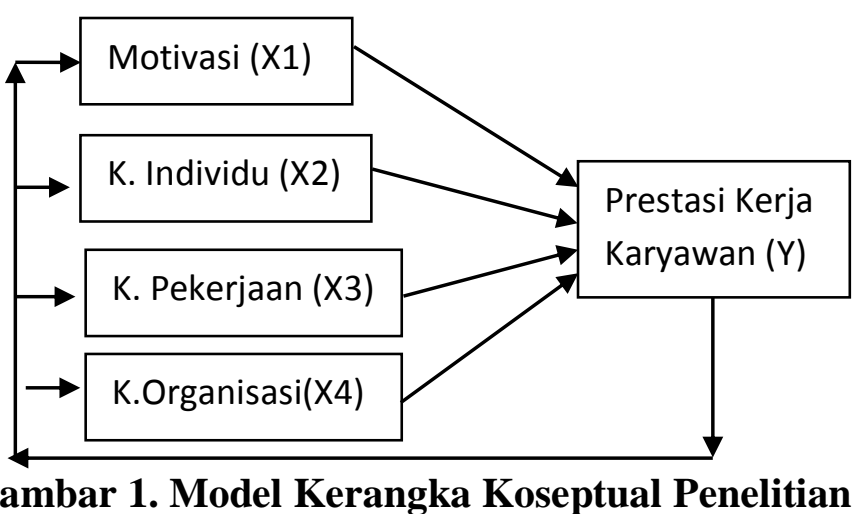

Untuk membuktikan hubungan-hubungan yang digambarkan dalam kerangka pemikiran tersebut di atas, selanjutnya dikemukakan hipotesis penelitian yang berdasarkan pada rumusan masalah, penelitian terdahulu yang telah ada dan dari dukungan teori dan konsep. Hipotesa yang diajukan adalah sebagai berikut:

1. Terdapat pengaruh simultan antara Motivasi, Karakteristik Individu, Karakteristik Organisasi dan Karakteristik Pekerjaan terhadap prestasi kerja karyawan pada PT. Putra Indah Perkasa Banjarbaru Kal-Sel.

2. Terdapat pengaruh parsial antara Motivasi, Karakteristik Individu, Karakteristik Organisasi dan Karakteristik Pekerjaan terhadap prestasi kerja karyawan pada PT. Putra Indah Perkasa Banjarbaru Kal-Sel.

3. Karakteristik Individu perpengaruh dominan terhadap prestasi prestasi kerja karyawan pada PT. Putra Indah Perkasa Banjarbaru Kal-Sel.

\section{Metode Penelitian}

Desain penelitian ini termasuk jenis penelitian survey, yaitu penelitian yang mengambil sampel dari satu populasi dan menggunakan kusioener sebagai alat pengumpul data yang pokok. Pada umumnya unit analisa dalam penelitian survey adalah individu (Singarimbun, 1995). Metode penelitian survey merupakan metode yang memberikan pertanyaan terstruktur kepada sampel dari populasi dan dirancang untuk memperoleh informasi dari responden (Widayat dan Amirullah, 2002). Oleh sebab itu unit analisa dalam penelitian ini adalah PT. Putra Indah Perkasa Banjarbaru Kal- Sel. 
Dalam penelitian ini terdapat dua jenis variable, yaitu variable bebas berupa motivasi (Independent Variable) dan variable tergantung berupa preatasi kerja (Dependent Variable) karyawan PT. Putra Indah Perkasa banjarbaru Kal- Sel dengan penjelasan dan indikator sebagai berikut:

1. Variabel motivasi $\left(\mathrm{X}_{1}\right)$.

Menurut Herzberg (dalam Ivancevich, dkk, 2006) terdapat serangkaian kondisi intrinsik yang dapat membentuk motivasi yang kuat sehingga dapat menghasilkan kinerja yang baik.Kondisi ini disebut faktor motivator. Yang termasuk ke dalam faktor motivator adalah

a. Prestasi $\left(\mathrm{x}_{1.1}\right)$

Aspek ini berhubungan dengan usaha yang dilakukan seseorang untuk mencapai prestasi kerja yang optimal.

b. Tanggung jawab $\left(\mathrm{x}_{1.2}\right)$

Aspek ini meliputi hal-hal yang berhubungan dengan tanggung jawab dan otoritas pada karyawan

c. Kemajuan $\left(\mathrm{x}_{1.3}\right)$

Aspek ini berhubungan dengan kesempatan karyawan untuk dapat maju dalam pekerjaannya.

d. Pekerjaan itu sendiri $\left(\mathrm{x}_{1.4}\right)$

Aspek ini berhubungan dengan tantangan yang dirasakan karyawan dari pekerjaannya.

e. Penghargaan $\left(\mathrm{x}_{1.5}\right)$

Aspek ini berhubungan dengan pengakuan atau penghargaan yang diberikan kepada karyawan atas kinerjanya.

2. Variable Karakteristik Individu $\left(\mathrm{X}_{2}\right)$.

Karakteristik individu adalah ciri pribadi yang obyektif serta membedakan dari orang lain dan mudah diperoleh dari rekam pribadi atau riwayat hidup seseorang. Indicator ini selanjutnya dijabarkan kedalam item-item yang terdiri dari :

a. Kebutuhan material $\left(\mathrm{x}_{2.1}\right)$, yaitu kebutuhan fisik yang menunjang kehidupan atau pelaksanaan pekerjaan yang terdiri dari pemenuhan kebutuhan makanan dan minuman, pakaian dinas, perumahan dinas, dan kendaraan dinas.

b. Kebutuhan non materiel $\left(\mathrm{X}_{2.2}\right)$, kebutuhan untuk konsumsi rohani yang terdiri dari rasa aman, penghargaan prestasi dan aktualisasi diri.

c. Pendidikan $\left(\mathrm{X}_{2.3}\right)$, yaitu pendidikan formal dan non formal yang pernah diperoleh pegawai. Pendidikan formal: SD,SLTP, SLTA, D3, S1, dan S2. Pendidikan nonformal: diklat penjenjangan atau structural, diklat teknis, dan kursus atau diklat lain.

d. Nilai $\left(\mathrm{X}_{2.4}\right)$, yaitu harga taksiran kadar/mutu/isi dan sifat yang penting bagi kemanusiaan. Nilai mengandung unsure pertimbangan. Mengembangkan gagasan individu mengenai apa yang benar, yang baik atau apa yang diinginkan. Nilai mengandung atribut isi ialah mengapa suatu modus (cara) perilaku adalah penting dan atribut intensitas yaitu berapa besaran kebesaran suatu modul perilaku, dimana secara sadar atau tidak nilai itu diresapi sebagai standar sehingga seseorang dapat menjadikannya pedoman dalam bertindak. Secara hirarkis nilai seorang individu menurut intensitasnya disebut system nilai yang diidentifikasikan dari kepentingan relative yang diberikan terhadap nilai-nilai kebebasan, kesenangan, hormat diri, kejujuran, kepatuhan dan kesamaan item diukur dari kedisiplinan dan tingkat kesetiaan.

e. Sikap $\left(\mathrm{X}_{2.5}\right)$, yaitu pernyatan obyektif dan pertimbangan evaluative tentang sesuatu peristiwa. Sikap merupakan cerminan perasaan seseorang terhadap sesuatu. Item ini diukur dari tanggung jawab yang diperhatikan dalam pelaksanaan tugas. 
f. Minat $\left(\mathrm{X}_{2.6}\right)$, adalah kecenderungan hati seseorang yang tinggi terhadap sesuatu yang menunjukan gairah dan keinginannya. Item ini diukur dari kecenderungan untuk menyenangi atau tidak suatu pekerjaan.

3. Variable Karakteristik Pekerjaan $\left(\mathrm{X}_{3}\right)$

Karakteristik pekerjaan adalah segala aspek dari sutu pekerjaan yang menjelaskan sifatsifat umum dan dicerminkan dalam persepsi oleh yang mengerjakan ( pegawai), kesiapan mental yang dipengaruhi oleh pengalaman seseorang terhadap obyek dan situasi yang berhubungan. Indicator ini dijabarkan dalam item-item yang terdiri dari:

a. Aneka kecakapan/keterampilan ( $\left.\mathrm{X}_{3-1}\right)$, menujukan bahwa aneka pekerjaan menuntut adanya keterampilan yang beragam terdiri dari:

1) Kemampuan intelektual ( pengetahuan)

2) Kemampuan fisik (keterampilan)

3) Kemampuan sikap

b. Identitas tugas $\left(\mathrm{X}_{3-2}\right)$, merupakan suatu urutan terinci dalam proses perencanaan dan pelaksanaan pekerjaan. Item diukur dari pemahaman pegawai terhadap prosedur kerja, tingkat kecermatan dan ketelitian pegawai dalam perencanaan pekerjaan, tingkat kesanggupan dan ketekunan pegawai dalam melaksanakan tugas.

c. Otonomi ( $\mathrm{X}_{3-3}$ ), adalah suatu tingkat dalam pekerjaan yang memberikan pegawai kebebasan dalam kemandirian merencanakan dan melaksanakan tugas-tugasnya. Item ini diukur dari: tingkat kemandirian dalam merencanakan pekerjaan, tingkat kebebasan dalam menyelesaikan tugasnya, tingkat kemampuannya menyampaikan pendapat ( inisiatif) selama menyelesaikan tugas.

d. Umpan balik ( $\left.\mathrm{X}_{3-4}\right)$, menunjukan pada tingkat dimana pegawai mendapatkan informasi mengenai keefektifan pekerjaannya. Item ini diukur dari pengetahuan karyawan tentang seberapa jauh prestasi yang telah dicapai dalam kurun waktu tertentu ( informasi tentang hasil kerja), pengetahuan pegawai bahwa atasan cukup puas dengan pekerjaan yang telah dilaksanakannya ( memahami selera atasan), dan intensitas pegawai menerima informasi tentang pelaksanaan pekerjaannya.

4. Variable Karakteristik Organisasi $\left(\mathrm{X}_{4}\right)$

Karakteristik organisasi, didefinisikan sebagai dimensi organisasi yang akan mempengaruhi tindakan dan kesadaran tiap pegawai dalam aktivitas sehari-hari saat bekerja, Swasto $(1997 ; 6)$. Variable ini dijabarkan kedalam item-item yang terdiri dari:

a. Kultur $\left(\mathrm{X}_{4-1}\right)$, budaya yang dikembangkan orang untuk mengatasi perubahan. Perwujudan berupa tindakan nyata yang dapat diukur dari kebiasaan misalnya cara bekerja dan bergaul.

b. Persepsi $\left(\mathrm{X}_{4-2}\right)$, pandangan pegawai terhadap lingkungan kerjanya, diamati dari cara pegawai mengartikan lingkunan kerjanya.

c. Kerja sama $\left(\mathrm{X}_{4-3}\right)$,kemampuan pegawai untuk melaksanakan pekerjaan bersam-sama dengan orang lain. Item ini dapat diukur melalui: kemampuan menyelesaikan tugastugas orang lain, kemampuan menghargai pendapat orang lain dan kemampuan beradaptasi.

d. Gaya kepemimpinan (X 4-4), adalah model penerapan kepemimpinan seseorang. Terdapat empat gaya kepemimpinan yaitu: delegasi, demokrasi, konsultasi dan instruksi. Item ini akan diukur melalui: penerapan model kepemimpinan, pengambilan keputusan, penetapan prioritas, tingkat ketegasan dan konsistensi, kemampuan memotivasi dan mengukur kapasitas serta tingkat perhatian bawahan. 
e. Peraturan dan kebijakan ( $\mathrm{X}_{4-5}$ ), peraturan dan kebijaksanaan yang dipedomi untuk melaksanakan tugas atau pekerjaan. Item ini diukur dari prosedur kerja, desain pekerjaan, program pengembangan/pelatihan, kebijaksanaan kepegawaian, system penggajian, pemberiaan penghargaan serta misi organisasi.

5. Variabel Prestasi Kerja (Y)

konsep prestasi kerja yang didefinisikan sebagai hasil kerja terbaik yang telah dicapai karyawan sesuai dengan standar yang ditetapkan dalam kurun waktu tertentu. Berdasarkan definisi ini:

a. Hasil Kerja.

Hasil kerja, yaitu hasil kerja senyatanya yang di peroleh pegawai dan merupakan hasil kerja optimal yang bisa diraih dari standard an waktu yang telah ditentukan. Indicator ini diukur:

1) Kualitas/mutunya bagus yaitu: halus, teliti, bersih dan hemat.

2) Kualitas kerjanya tinggi meliputi: kecepatan, ketepatan waktu, banyaknya keahlian yang dimiliki.

3) Pengetahuan tentang pekerjaan antara lain: pemahaman prosedur kerja, perencanaan pekerjaan yang jeli, danketekunan dalam pelaksanan kerja.

b. Produktivitas.

Produktivitas adalah suatu ukuran kinerja yang mencakup keefektifan dan keefisienan. Keefektifan adalah pencapaian tujuan/target sedangkan efisiensi merupakan rasio dan keluaran efektif terhadap masukan yang diperlukan untuk mencapai tujuan itu. Jadi hubungan antara hasil nyata/fisik berupa barang atau jasa dari suatu tujuan yang dicapai dengan mentransfer masukan keluaran dengan biaya paling rendah. Dengan demikian merupakan perbandingan antara totalitas pengeluaran pada waktu tertentu dibagi totalitas masukan selama periode tersebut. Indicator ini terdiri dari item-item sebagai berikut :

1) Kecakapan yaitu kemampuan, kesanggupan melaksanakan tugas hingga tugas tuntas.

2) Keterampilan yaitu kecekatan dalam memanfaatkan sarana yang ada antara lain adaptif, komunikatif, koordinatif, delegatif, kepemimpinan dan pengambilan keputusan.

3) Pengalaman yang luas ditandai dari banyaknya inisiatif dan kreatifitas.

c. Perubahan Perilaku.

Perubahan perilaku ialah perubahannya perilaku yang semakin baik diwujudkan dalam item penampilan kerja yang mengesankan dan mencerminkan nilai tertinggi terhadap semua criteria tersebut diatas yang dapat diukur dari: semangat kerja yang tinggi, rajin, berkepribadian yang kuat (jujur, sopan, ramah), mandiri, percaya diri, berani mengambil keputusan, berani menanggung resiko, efisien dan efektif.

Populasi yang ditetapkan pada penelitian ini adalah seluruh karyawan PT. Putra Indah Perkasa Banjarbaru Kal-Sel. Total populasi pada tahun 2017 ini adalah 200 orang. Sampel ditarik berdasarkan statifield random sampling yang diambil secara acak (Indrianto, 1999:124) dan untuk itu dari total populasi 200 orang diambil 25\% nya menjadi 50 orang yang akan diteliti (Arikunto, Suharsini; 1993), begitu pula menurut (Hair F Joseph,) setiap satu variable bebas pada analisa regresi sebanding dengan 15-20 sampel. Sampel dalam penelitian ini berdasarkan variable-variabel yang diajukan peneliti, diambil berdasarkan atas 
strata pendidikan pada departemen/bagian dari karyawan PT.Putra Indah Perkas Banjarbaru Kal-Sel.

\section{Hasil Penelitian dan Pembahasan}

Tujuan dalam melakukan analisa regresi berganda adalah untuk mengetahui sejauh mana tingkat pengaruh antara variable independen, yaitu yang terdiri dari Motivasi (X1), Karakteristik Individu (X2), Karakteristik Pekerjaan (X3), dan Karakteristik Organisasi (X4) terhadap variable dependen yaitu prestasi kerja karyawan, baik secara simultan maupun secara parsial.

Hipotesa pertama dalam penelitian ini adalah: diduga ada pengaruh yang signifikan antara variable karakteristik individu, karakteristik pekerjaan,dan karakteristik organisasi secara simultan terhadap variable dependen yaitu prestasi kerja karyawan. Untuk menguji hipotesis secara bersama-sama, ditemukan bahwa signifikasi F sebesar 0.000. jadi kalau dibandingkan dengan alpha adalah $\mathrm{p}<\alpha$ atau $\mathrm{p}<0.005$. keputusan terhadap hal tersebut adalah Ho ditolak, Ha diterima. Hal tersebut berarti ada pengaruh yang signifikan secra bersama-sama antara variable motivasi yang terdiri dari karakteristik individu, karakteristik pekerjaan, dan karakteristik organisasi terhadap variable dependen yaitu prestasi kerja karyawan. Dengan signifikasi $\mathrm{F}=0.000$ yang jauh lebih kecil dari 0.05 maka model tersebut dapat dipergunakan untuk memperbaiki prestasi kerja karyawan.

Uji hipotasis kedua dalam penelitian ini adalah: diduga terdapat pengaruh yang signifikan secara parsial antara variable karakteristik individu, karakteristik pekerjaan, dan karakteristik organisasi terhadap variable dependen yaitu prestasi kerja karyawan. Dasar pengambilan keputusannya adalah dengan melihat probabilitasnya. Jika $\mathrm{p}<0.05$ maka Ho ditolak, Ha diterima atau $\mathrm{p}>0.05$, maka Ho diterima dan Ha ditolak. Variabel karakteristik individu $\left(\mathrm{X}_{1}\right)$ memiliki signifikasi 0.043 , karena sig $(\mathrm{t})<0.05$, maka Ho ditolak dan Ha diterima. Hal ini berarti bahwa terdapat pengaruh yang signifikan antara variable karakteristik individu terhadap prestasi kerja karyawan. Nilai koefisien regresi (b) untuk variable karakteristik individu sebesar 0.589 dan bertanda positif, hal ini berarti bahwa setiap perbaikan kondisi individu memiliki pengaruh yang positif terhadap prestasi kerja karyawan. Koefisien determinasi $\left(\mathrm{r}^{2}\right)$ sebesar 0.133 , hal ini menunjukan bahwa kontribusi variable karakteristik individu terhadap prestasi kerja karyawan sebesar $13.3 \%$. Nilai koefisien korelasi $\left(\mathrm{r}^{2}\right)$ parsial variable karakteristik individu sebesar 0.562, hal ini menunjukan korelasi atau hubungan antara variable karakteristik individu dan prestasi kerja karyawan adalah cukup berpengaruh. Kesimpulan adalah hipotesis ini teruji bahwa terdapat pengaruh yang signifikan antara variable karakteristik individu terhadap prestasi kerja, dengan koefisien regresi (b) sebesar 0.589 dan kontribusinya terhadap prestasi kerja karyawan $13.3 \%$.

Variabel karakteristik individu $\left(\mathrm{X}_{2}\right)$ memiliki signifikasi 0.028 , karena sig $(\mathrm{t})<0.05$, maka Ho ditolak dan Ha diterima. Hal ini berarti bahwa terdapat pengaruh yang signifikan antara variable karakteristik pekerjaan terhadap prestasi kerja karyawan. Nilai koefisien regresi (b) untuk variable karakteristik pekerjaan sebesar 0.137 dan bertanda positif, hal ini berarti bahwa setiap perbaikan kondisi pekerjaan akan meningkatkan prestasi kerja karyawan bila variable bebas lainnya dianggap konstan. Koefisien determinasi $\left(r^{2}\right)$ sebesar 0.065, hal ini menunjukan bahwa kontribusi variable karakteristik pekerjaan terhadap prestasi kerja karyawan sebesar $6.5 \%$. Nilai koefisien korelasi $\left(r^{2}\right)$ parsial variable karakteristik pekerjaan sebesar 0.144, hal ini menunjukan korelasi atau hubungan antara variable karakteristik pekerjaan dan prestasi kerja karyawan adalah kurang berpengaruh. Kesimpulan adalah hipotesis ini teruji bahwa terdapat pengaruh yang signifikan antara variable karakteristik pekerjaan terhadap prestasi kerja, dengan koefisien regresi (b) sebesar 0.137 dan kontribusinya terhadap prestasi kerja karyawan $6.5 \%$. 
Variabel karakteristik organisasi $\left(\mathrm{X}_{3}\right)$ memiliki signifikasi 0.038 , karena sig $(\mathrm{t})<0.05$, maka Ho ditolak dan Ha diterima. Hal ini berarti bahwa terdapat pengaruh yang signifikan antara variable karakteristik organisasi terhadap prestasi kerja karyawan. Nilai koefisien regresi (b) untuk variable karakteristik organisasi sebesar 0.156 dan bertanda positif, hal ini berarti bahwa setiap perbaikan kondisi pekerjaan yang meningkat satu-satuan akan meningkatkan prestasi kerja sebesar 0,15 satuan bila variable bebas lainnya dianggap konstan. Koefisien determinasi $\left(\mathrm{r}^{2}\right)$ sebesar 0.055 , hal ini menunjukan bahwa kontribusi variable karakteristik organisasi terhadap prestasi kerja karyawan sebesar $05.5 \%$. Nilai koefisien korelasi $\left(\mathrm{r}^{2}\right)$ parsial variable karakteristik organisasi sebesar 0.170 , hal ini menunjukan korelasi atau hubungan antara variable karakteristik pekerjaan dan prestasi kerja karyawan adalah kurang berpengaruh (pengaruhnya kecil). Kesimpulan adalah hipotesis ini teruji bahwa terdapat pengaruh yang signifikan antara variable karakteristik organisasi terhadap prestasi kerja, dengan koefisien regresi (b) sebesar 0.156 dan kontribusinya terhadap prestasi kerja karyawan 5.5\%.

Berdasarkan pengujian hipotesa tersebut dapat diperoleh persamaan regresi tentang pengaruh factor motivasi terhadap prestasi kerja karyawan, dengan asumsi bahwa variable lainnya selain variable bebas yang ditetapkan dalam penelitian ini bersifat konstan:

$$
Y=-0,684+0,613 X_{1}+0,519 X_{2}+0,526 X_{3}
$$

Penelitian ini bertujuan untuk mengetahui pengaruh factor-faktor motivasi yang terdiri dari : karakteristik individu, karakteristik pekerjaan, dan karakteristik organisasi terhadap prestasi kerja karyawan, baik secara simultan maupun parsial dan variable mana yang berpengaruh lebih dominan terhadap prestasi kerja.

Dengan melihat hasil analisis uji pengaruh parsial, disarankan sebaiknya PT. Putra Indah Perkasa lebih memfokuskan pada sisi karakteristik individu tanpa mengabaikan karakteristik pekerjaan dan karakteristik organisasi, karena dalam usaha peningkatan satu sisi tidak dapat berdiri sendiri melainkan saling mempengaruhi..

Dengan ditolaknya Ho dan Ha diterima pada penelitian ini berarti mendukung tinjauan empiris Muh. Ilham (1998) dalam motivasi kerja dan pelatihan serta pengaruhnya terhadap kinerja karyawan menyatakan bahwa variable motivasi kerja (minat dan kemampuan) dan variable pendidikan, pelatihan (pelaksanaan on the job training \& pelaksanaan off the job training) mempunyai pengaruh terhadap kinerja karyawan. Sedangkan Fauzan .R (2001) dalam pengaruh motivasi kerja terhadap kinerja pegawai administrasi di Universitas Tanjungpura Pontianak yang menyatakan bahwa variable-variabel dalam motivasi internal (prestasi, pengakuan, pekerjaan itu sendiri, tanggung jawab, kesempatan untuk maju dan tumbuh) dan motivasi eksternal ( gaji, kondisi kerja, fisik, supervisi, hubungan dengan rekan sekerja, keamanan, kebijakan organisasi) secara simultan dan secara parsial mempunyai pengaruh yang signifikan terhadap kinerja pegawai.

Hasil penelitian ini juga sesuai dengan teori yang dikemukakan oleh Gomes (1995) bahwa kinerja karyawan senantiasa berkaitan erat dengan dua factor utama, yaitu (1) kesediaan atau motivasi karyawan untuk bekerja yang menimbulkan usaha karyawan , dan (2) kemampuan pegawai untuk melaksanakan pekerjaan. Dengan kata lain, kinerja adalah fungsi interaksi antara motivasi dengan kemampuan.

Motivasi memiliki pengaruh terhadap prestasi kerja karyawan, walaupun pada dasarnya prestasi kerja sesorang tidak hanya ditentukan oleh motivasi saja, melainkan dapat pula dipengaruhi oleh factor-faktor lain seperti pelatihan, kesempatan dan lain-lain. Akan tetapi dari data temuan hasil penelitian di beberapa bagian pada PT.Putra Indah Perkasa menyebutkan bahwa motivasi memiliki pengaruh yang signifikan terhadap peningkatan 
prestasi kerja karyawan. Karena dengan motivasi, secara otomatis semangat kerja seorang karyawan akan dapat meningkat, sehingga pada akhirnya dapat meningkatkan prestasi kerja itu sendiri. Hal ini dibuktikan dengan hasil temuan angka-angka, baik secara parsial maupun simultan yang mendukung penelitian ini, selain teori yang juga menguatkan temuan dalam penelitian ini.

\section{Kesimpulan}

Hasil penelitian ini memberikan beberapa temuan yang berkaitan dengan pengaruh factor motivasi terhadap prestasi kerja karyawan PT. Putra Indah Perkasa. Secara umum penelitian ini disimpulkan sebagai berikut:

1. Berdasarkan hasil analisa terhadap karyawan di sejumlah bagian pada PT. Putra Indah Perkasa, dan pengujian dari variable motivasi (X1), Karakteristik Individu (X2), Karakteristik Pekerjaan (X3), Karakteristik Organisasi (X4) menunjukan bahwa semua variabel secara parsial maupun simultan (bersam-sama) berpengaruh signifikan. Hal tersebut menunjukan bahwa factor motivasi sangat berpengaruh terhadap prestasi kerja karyawan pada PT. Putra Indah Perkasa.

2. Dengan melihat sedemikian berpengaruhnya motivasi, bahwa pemberian motivasi terhadap karyawan adalah suatu langkah strategis guna meningkatkan kualitas dan kuantitas sumberdaya manusia yang mmempunyai pengaruh kuat terhadap prestasi dan produktivitas kerja karyawan yang pada akhirnya kinerja menjadi lebih baik, sehingga dapat menjadi daya saing yang handal bagi perusahaan dimasa sekarang.

3. Dari hasil analisa penelitian diketahui bahwa karakteristik individu (X1) berpengaruh lebih dominan terhadap prestasi kerja karyawan (Y) disbanding dengan karakteristik pekerjaan (X2) dan karakteristik organisasi (X3), menunjukan bahwa dalam usaha peningkatan prestasi kerja karyawan lebih dipengaruhi pemenuhan yang sifatnya individu karyawan, sepertiL pemenuhan kebutuhan materil dan non materil, pendidikan dan pelatihan, nilai, sikap, dan minat yang dirasa layak dengan kemampuan dan produktivitas, dan sesuai dengan kebutuhan individu masing-masing. Jika karyawan merasa bahwa usahanya tidak dihargai dengan pemenuhan kebutuhan deperti diatas, maka prestasi kerja karyawan akan di bawah kemampuannya.

4. Kinerja karyawan akan dapat ditingkatkan apabila perusahaan memiliki komitmen yang tinggi terhadap perbaikan pada factor-faktor yang mempengaruhi motivasi itu sendiri, seperti: karakteristik individu, karakteristik pekerjaan, dan karakteristik organisasi.

\section{DAFTAR PUSTAKA}

Arikunto, 1993. Prosedur Penelitian: Suatu Pendekatan Praktek. Edisi revisi keempat, Penerbit Rineka Cipta - Jakarta.

Abdul Azis, 1997, Faktor-Faktor yang Mempengaruhi Evaluasi Kinerja para Pejabat, Tesis, PMM, Universitas Brawijaya Malang.

Bernardin, H. Jhon and Joyce E.A Rusel, 1993. Human Resource Management. Singapore, McGraw-Hill, Inc.

Bimo Walgito, 2001. Psikologi Sosial ( suatu pengantar), Edisi kedua, Andi - Yogyakarta.

Chusway, Barry, 1996. Manajemen Sumberdaya Manusia. Terjemahan, PT. Elex Media Komputindo, Jakarta.

Dessler, Dery, 1997. Manajemn Sumberdaya Manusia, 7e, jilid I\&II, Edisi Indonesia, Penerbit PT. Prenhallindo, Jakarta.

Dharma, Agus. 1989. Manajemen Prestasi Kerja. Edisi Pertama, Rajawali - Jakarta.

Fisher, Cynthia D., Schoenfeldt, Lyle F., James B, 1993. Human Resource Management, 2nd edition, Houghton Miffin Company, USA. 
Gibson, J.L., Ivancevich, J.M. Donnely Jr. J.H. 1996. Organisasi dan Manajemen Perilaku, Struktur dan Proses. Alih Bahasa: Wahid, Joerban, Jakarta: Erlangga.

Gomes, Faustino Cardosa, 1995. Manajemen Sumber Daya Manusia. Edisi Pertama. Andi Offset, Yogyakarta.

Greer, Charles R., 2001. Strategic Human Resource Management: A General Managerial Approach, 2nd edition. Pretice- Hall Inc.USA

Handoko, Hani T, 1996. Manajemen Personalia dan Sumber Daya Manusia, BPFE, Yogyakarta.

Heneman, Herbert G. Schwab, Donald P Fossum, J and Dryer (1981). Managing Personnel and Human Resource Strategies and Problems. Dowjoness, Irwin- Illions.

Ilham, Muh, 1998, Motivasi Kerja dan Pelatihan serta pengaruhnya terhadap kinerja karyawan, Tesis, PMM, Universitas Brawijaya Malang.

Islamy, M. Irfan, 1995, Motivasi dan Kepemimpinan. FIA Universitas Brawijaya Malang.

Maylanie, Johanna .T, 2005, Pengaruh Faktor Motivasi terhadap Prestasi kerja Karyawan. Tesis, PMM, Universitas Brawijaya Malang.

Kerlinger, Fred, N. 1995. Foundation of Behavior Research. 3th edition. Edisi Bahasa Indonesia : Asas-asas penelitian Behavioral. Penerjemah Simatupang Landung R. Editor J. Koesoemanto. Cetakan keempat Gajah Mada University Press Yogyakarta.

Kreitner, Robert and Angelo Kinicki., 1998. Organizational Behavior, Fourth Edition, McGraw- Hill Companies, Inc.

Miller, Danny, Droge Cornelia, Vickery, Shawnee, 1997. Celebrating The Essential: The Impact of Performance on The Functional Favoritism of CEO in Two Contexts, Journey of Management (JOM), Vol:23, ISS:2, p: 147-168.

Nedler an Leonard, 1990. Human Resource Development, The Handbook of Human Resource Development. Leonard \& Zeace Nadler (ed). 2nd edition. John Wiley \& Sons Inc. Canada.

R, Fauzan, 2001, Pengaruh Motivasi Kerja terhadap Kinerja Pegawai Administrasi di Universitas Tanjungpura Pontianak, Tesis, PMM, Universitas Brawijaya Malang.

Robbins, Stephen P. 1990. Organization Behavior: Concepts, Controversis, and Application. New Jersey: Prentice Hall International. Inc Englewood Cliffs.

Siagian, Sondang P. 1988. Teori dan Praktek Kepemimpinan, PT. Rineka Cipta, Jakarta.

Simamora, Henry., 1995. Manajemen Sumber Daya Manusia, Penerbit STIE YKPN, Yogyakarta.

Sujak, Abi, 1992. Kepemimpinan Manajer: Konsep Dasar dan Implikasi. Cetakan kelima, Rajawali, Jakarta.

Stoner, James F; Freeman, Edward R; and Gilbert, Daniel R., 1995. Management. 6th Ed, Prentice- Hall, Inc.

Swasto, Bambang, 1996. Pengembangan Sumberdaya Manusia, Pengaruhnya Terhadap Kinerja dan Imbalan. FIA dan FAPET Universitas Brawijaya Malang.

Ubaldy, 1997, Denmark's Focus on Employee Motivational and Education Creates Ideal Center Environement, Journal April 1997.

Wagner, John A III, Leana, Carrie R, Locke, Edwin A, Schewiger, Cavid M, 1997. Cognitive and Motivational Frameworks In US, Research and Participation: A MetaAnalysis of Primary Effects, Journal of Organizational Behavior (JBH), Vol: 18, ISS, $\mathrm{p}: 49-65$.

Wahjosumijo., 1984. Kepemimpinan dan Motivasi, Penerbit Galia Indonesia, Jakarta.

Widayat dan Amirullah, 2002. Riset Bisnis. Penerbit Graha Ilmu, Yogyakarta.

Yacob, 1998. Pengaruh Karakteristik Individu, Karakteristik Pekerjaan, Karakteristik Organisasi Terhadap Kinerja Karyawan, Tesis, PMM, Universitas Brawijaya Malang. 